\title{
edoc
}

Institutional Repository of the University of Basel

University Library

Schoenbeinstrasse 18-20

CH-4056 Basel, Switzerland

http://edoc.unibas.ch/

Year: 2012

\section{Conflict of interest related to management and board payments - profit-based remuneration systems make things worse}

Handschin, Lukas

Posted at edoc, University of Basel

Official URL: http://edoc.unibas.ch/dok/A6056170

Originally published as:

Handschin, Lukas. (2012) Conflict of interest related to management and board payments - profit-based remuneration systems make things worse. In: Conflict of Interest in Global, Public and Corporate Governance. Cambridge, S. 288-307.

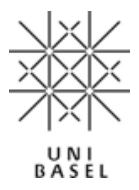




\title{
Conflict of interest related to management and board payments - profit-based remuneration systems make things worse
}

\author{
LUKAS HANDSCHIN*
}

\section{Introduction}

One of the first topics which come to one's mind when discussing conflicts of interest in the corporate world is the determination of payments to board members and management, especially if the board and the management fix their own remunerations. ${ }^{1}$ This bears the risk that the judgement (though competent) will not be exercised properly. ${ }^{2}$ In order to reduce or eliminate this risk, rules are set up which link the remuneration of the board and the management to objective/impartial criteria such as economic or performance figures, in particular the company's profit. However, such rules do not solve the conflict of interest but in fact make things worse. The board and the management enjoy some discretion when valuating assets and liabilities of the company. It is paramount for the stability and sustainability of the company to ensure that such decisions are made in the best interest of the company. If the board or the management have an own interest in a high profit, ${ }^{3}$ there is a risk that

* I thank Andreas Steffen, LL.M. for his expert research assistance and Kim Farragher for her support with the drafting of this chapter in English.

1 A conflict of interest arises when a person or a legal entity has to safeguard the interest of another person or legal entity and an action or omission taken thereby potentially conflicts with own interests or those of third parties. See, e.g. Watter and Maizar, 'Structure of Executive Compensation and Conflicts of Interests', p. 31, n. 2. For the non-conflict rule see Bray v. Ford [1896] AC 44 at pp. 51 et seq.; French, Mayson and Ryan, Company Law, 16.9.

2 Davis, 'Empirical research on conflict of interest: a critical look', Chapter 3 in this volume, p. 58.

3 'Give them stock options, and paradoxically their conflict of interest becomes potentially even more pronounced, as many recent examples in the corporate world have shown all too well': Friedberg, 'Conflict of interest from the perspective of the sociology of organised action', Chapter 2 in this volume, p. 44. 
they overvaluate assets and undervaluate liabilities to show exaggerated profits and thus undermine the company's equity by excessive dividend payments.

\section{Problem}

\subsection{How to regulate management and board payment?}

In most jurisdictions it is the board itself which determines the remuneration of its members and the top management. ${ }^{4}$ It is obvious that there is an inherent risk that the respective decisions are not only taken in the best interest of the company, but also in the interest of the board members themselves.

This also holds true if the board member concerned cannot participate in the vote regarding his own salary: ${ }^{5}$ the fact that the board members in question abstain from voting when it comes to their salary does not effectively control the existing conflict of interest. Often there is

${ }^{4}$ For Switzerland: Art. 716a(1) CO. This holds at least true for the regime of remuneration, setting the (total) amount of the remuneration may be delegated to the general assembly. Watter and Roth Pellanda, 'Art. 716a OR', MN 46, primarily the competence derives from the articles and either lies with the board or the assembly. Peter Böckli, Schweizer Aktienrecht, $\S 13, \mathrm{MN} 239$. However, if not regulated in the articles the competence lies with the board according to Art. 716(1) CO; in the UK, in the absence of a provision in the articles of the company, the board's decision on its remuneration is in practice accepted: French, Mayson and Ryan, Company Law, 15.9.1.2.; listed companies form a remuneration committee, composed of the independent non-executive directors according to the Combined Code on Corporate Governance (B.2.1. and B.2.2). US: the American Bar Association recommends that the remuneration be set by non-executive and independent board members. American Bar Association, Corporate Directors' Guidebook, pp. 69 et seq.; listed companies at the NYSE or NASDAQ are obliged to determine the remuneration in this way. Hamilton et al., Responsibilities of Corporate Officers and Directors under Federal Securities Law, p. 33; Germany has a two-tier board system, the non-executive board controls the executive board, and thus, business management ( $\S 111(1)$ of the German Stock Corporation Act (Aktiengesetz, AktG)). The general remuneration is set by the general assembly in the articles. For consulting services that exceed those owed under the general duty as a board member an additional remuneration may be paid to the board members; over this remuneration the board may decide itself ( $114(1) \mathrm{AktG})$; not so in Japan: the general assembly decides over the general remuneration of the board ( $\$ 269$ Japanese Commercial Code/Shôhô, Law No. 138/2003 (JCC)). For incentivised payments $\S \S 281(1)$ ss. 4 and 283(1) JCC.

5 Böckli, Schweizer Aktienrecht, § 13, MN 239a; also referred to as 'mutual back scratching' Davis, Worthington and Micheler, Gower and Davies' Principles of Modern Company Law, pp. 14-13. In Japan this seems to be clear: as the competence to decide over their own remuneration would amount to various problems, this competence lies with the assembly. Ichiro et al., Gesellschaftsrecht in Japan, p. 484. 
a tacit understanding regarding a general level of remuneration among all board members. Member ' $A$ ' agrees to the pay rise in favour of member ' $\mathrm{B}$ ' (who abstains) and vice versa. The decision-making procedure within the board is intransparent and the informal decision-making procedures regarding the general level of remuneration cannot be controlled effectively. ${ }^{6}$

The law as well as the public and academic discussion (especially after the failure of companies with highly paid executives in the course of the economic crisis of 2008-2009) have addressed the problem and developed concepts on how to handle this issue. ${ }^{7}$

In practically all jurisdictions, corporations are required to disclose the payments to the board members of public companies. Some legislators require only the disclosure of the aggregate sum, ${ }^{8}$ others the remuneration of each member by name, ${ }^{9}$ or the aggregate sum and the highest remuneration paid to an individual member. ${ }^{10}$ The problem of the transparency concept is that it works only on the basis of shame by exposing high paid executives and board members to the public discussion. The concept works in cultures with strong egalitarian structures such as Germany, Sweden or Japan, however not so much in an environment where it is broadly culturally accepted 'to make money'. Further, the shame-based concept works only if the exposed executives or board members react to shame: the shameless and reckless are not impressed by public disapproval.

${ }^{6}$ Whether rules regarding the prevention of conflict of interest should rely primarily on procedural rules such as disclosure and voting rights, as proposed by Bahar and Morand, must therefore be put in question. See Bahar and Morand, 'Taking conflict of interest in corporate law seriously - direct and indirect rules addressing the agency problem, Chapter 17 in this volume, p. 329.

7 Stark, 'Conflict of interest and the furore over banker compensation', Chapter 15 in this volume.

8 UK: small companies under SI 2008/409, Sch. 3, para. 1 and SI 2008/410, Sch. 5, para. 1; Germany: $\S 285$ ss. 9 lit. a Handelsgesetzbuch (HGB).

9 Switzerland: for listed companies in general Art. 663bbis CO, for the disclosure of stock and stock options held by the board Art. 663c(3) CO; UK: listed companies SI 2008/410, Sch. 8. Also Davis, Worthington and Micheler, Gower and Davies Principles of Modern Company Law, pp. 14-17; Germany: for listed companies s. 5.4.5 of the German Corporate Governance Codex (DCGK).

10 UK: unquoted large or medium-sized companies under SI 2008/410, Sch. 5 para. 2; US: the remuneration of the $\mathrm{CEO}$ and the four Executives with the highest remuneration according to Art. 402 of the S-K Regulation of the Securities and Exchange Commission: Hamilton, Executive Compensation and Related-party Disclosure, pp. 301 et seq. 
The most effective way to eliminate conflict of interest seems to transfer the competence of deciding on such payments on behalf of the company from the board to the assembly of shareholders, or, from the agent to the principal. ${ }^{11}$ Such systems are discussed in many countries, ${ }^{12}$ but only effectively in force in Japan, ${ }^{13}$ with regard to an advisory vote in the $\mathrm{UK}^{14}$ and to some extent in Germany. ${ }^{15}$ The disadvantage of this system lies in the structure of the general assembly of shareholders, clearly within public companies. First, the assembly of shareholders convenes as a rule only once a year. Secondly, the discussion is public, making it difficult to include delicate issues which cover company secrets and discussing the reasoning for the proposed remuneration openly.

The assembly of shareholders is only then an efficient panel to decide on board and management pay, if it is not public and controlled by one or a few shareholders. In the latter case, a formal competence of the shareholders' assembly to decide on board remuneration is not necessary, since one or a few shareholders control the board and the management and further the decision on their remuneration based on their informal power as dominant shareholders. Controlling shareholders can always threaten a board member, by way of voting out, by refusing discharge or even by way of claiming damage. ${ }^{16}$ These control instruments are very effective and can as a result prevent the board from deciding on remunerations to which the shareholder will not agree.

11 For findings that seem to support this view: Bertrand and Mullainathan, Do CEOs Set Their Own Pay?, p. 38.

12 For Switzerland: Blanc and Zihler, 'Die neue aktienrechtlichen Vergütungsregeln gemäss dem Entwurf vom 5. Dezember 2008', pp. 67 et seq.; UK and US: for the discussion of shareholders' approval of directors' contracts see Cheffin and Thomas, 'Should Shareholders Have a Greater Say over Executive Pay?', pp. 277 et seq.

$13 \S 269$ JCC. For incentivised payments $\S \S 281(1)$ ss. 4 and 283(1) JCC.

14 Under the Listing Rules for certain share option schemes and other long-term incentive plans for companies admitted to the Official List and traded on the Main Market of the London Stock Exchange (LR 9.4); Davis, Worthington and Micheler, Gower and Davies Principles of Modern Company Law, pp. 14-15 and 23.

15 However, for further consulting a remuneration may be paid to the board members. On this remuneration the board may decide itself ( $\$ 114(1)$ AktG). The non-executive board (Aufsichtsrat) decides also on the remuneration of the executive board (Vorstand).

16 Indeed it has been shown that control of the management by dominant shareholders has a positive effect on exceeding management payment. See Gomez-Mejia, Larazza-Kintana and Makri, 'The Determinants of Executive Compensation in Family-controlled Public Corporations', pp. 226 et seq. 


\subsection{Eliminating conflict of interest by tying remuneration to impartial/objective criteria}

Therefore, a third option seems attractive: reducing or eliminating the conflict of interest by setting up rules which link the remuneration of the board and the executives to objective/impartial criteria such as economic or performance figures. This method disconnects the decision on the remuneration method from the decision on the effective remuneration. At first glance, the set-up of impartial/objective criteria reduces the conflict of interest.

Of course, a careful and anticipatory management will still be able to define the rules in ways that ensure high payments, but the problem of the conflict of interest seems reduced and the acceptance of the remuneration by the shareholders (and the public) is increased if it is performance-related. Many scholars and standards suggest performance-related remuneration formulas as a method to reduce the risk of inappropriate payments to board members and management. ${ }^{17}$ Also in the public perception, such models are favoured. ${ }^{18}$ They play a significant role in the practical world.

The fascination of this concept, however, conceals the large inherent risks of this system, which may at worst put the company at risk. ${ }^{19}$

\subsection{Reducing conflict of interest by profit-based remuneration systems may put the company at risk}

Such performance-based remuneration models bear the risk that the board and the management exercise their discretion concerning the financial statement, the definition of the distributable profit and the valuation of assets and liabilities not in the best interest of the company, but rather

17 Switzerland: Bühler, Regulierungen im Bereich der Corporate Governance, p. 511; US: Nikitin, 'USA', pp. 52 et seq. UK: Financial Reporting Council, The Combined Code on Corporate Governance, June 2006, at B.1; Germany: s. 5.4.5. DCGK; Switzerland: Appendix 1 lit. b ss. 3 of the Swiss Code of Best Practice for Corporate Governance. So it seemed that profit-based remuneration wås the solution to the principal-agent problem by synchronising shareholders' and the management's interest. See Rappaport, Creating Shareholder Value, pp. 3 et seq.

18 Barthold and Widmer, 'Regulierung der variablen Vergütung?', p. 1392.

19 Böckli, Schweizer Aktienrecht, § 8, MN 486; also G20 Working Group 1, Enhancing Sound Regulation and Strengthening Transparency, Final Report, 2009, pp. 32 et seq., available at http://rbidocs.rbi.org.in/rdocs/PublicationReport/Pdfs/20_010409.pdf (last accessed 26 June 2012). 
in their own interest, thus allowing them to achieve higher profit, and consequently, to receive higher bonus payments. The damage caused by this is in substance not the unjustified payment to the board and the management, but much more relevant is the 'collateral damage' which is caused by excessive dividend payments to shareholders. Such system may weaken the company's equity, and as a result, put the company at risk in case of economic aggravation. The risks of such performance-related models and the conflict of interest which they create are the subjects of this chapter.

\section{Financial control as a competence of the board of directors}

According to Article 716a(1) ss. $6 \mathrm{CO}$ the financial control and the preparation of the financial statements is a non-transferable and inalienable duty of the board of directors. The board is responsible for the preparation of the annual report which includes the financial statements and the motion to the general assembly of shareholders regarding the use of the distributable profit. The competence to prepare the financial statements includes the competence to apply valuation rules and to exercise discretion within the context of such rules, for example to determine the parameters to valuate an asset or to decide on the formation of provisions. ${ }^{20}$

This organisational rule - financial control as a duty of the board of directors - is seen in many jurisdictions. ${ }^{21}$

\section{Definition of the profit of the company}

\subsection{Basics}

'Income is increases in economic benefits during the accounting period in the form of inflows or enhancements of assets or decreases of liabilities that result in increases in equity, other than those relating to contributions from equity participants. ${ }^{\text {22 }}$ 'Expenses are decreases in

20 Watter and Roth Pellanda, 'Art. 716a OR', MN 6.

${ }^{21}$ Germany: § 111 AktG; UK: Mayson, French and Ryan, Company Law, 9.1; US: e.g. § 409 Sarbanes-Oxley-Act. The general duty of reporting does not necessarily lie with the board: Delaware corporations need not have a board at all and may implement a direct control by the shareholders. Welch and Turezyn, Folk on the Delaware General Corporation Law, $\S 141.1 .1$; Japan: $\S 281(1)$ and 283(1) JCC.

22 International Financial Reporting Standards (IFRS) Conceptual Framework, 4.25a. IFRS comprise amongst the IFRS Standards, the International Accounting Standards (IAS), the Interpretations originated from the International Financial Reporting Interpretations 
economic benefits during the accounting period in the form of outflows or depletions of assets or incurrences of liabilities that result in decreases in equity, other than those relating to distributions to equity participants. ${ }^{, 23}$ The aggregate sum of income and expenses is the profit.

The profit is the reference figure for dividend payments. After each fiscal year, the shareholders decide on the allocation of the increase in equity (profit), whether it should be distributed to the shareholders as dividends or kept in the company as retained earnings or reserves. ${ }^{24}$

\subsection{Cash-related elements of the profit}

The definition of income refers to 'inflows', the definition of expenses to 'outflows' of assets. These inflowing and outflowing assets can be of any nature, also cash. The cash part of the profit is the cash flow.'It shows the ability of the company to generate cash and the need of the company to use those cash flows. The cash flow is the aggregate sum of the cash flow from operating, investing and financing activities of the company. ${ }^{25}$

Cash flows from operating activities are primarily derived from the principal revenue producing activities of the enterprise. ${ }^{26}$ They include in particular cash receipts from the sale of goods and the rendering of services, cash payments to suppliers for goods and services and to employees.

The cash flow from investing activities shows the ability - or inability of a company to invest in resources intended to generate future income and cash flows. Examples of cash flows arising from investing activities are cash payments to acquire property, plant and equipment, intangibles and other long-term assets or cash receipts from sales of property, plant and equipment, intangibles and other long-term assets. The cash flow from investing activities is disclosed separately. ${ }^{27}$ It is, for example, an important piece of information whether a certain cash flow is the result

Committee (IFRIC), the Standing Interpretations Committee and the Framework for the Preparation and Presentation of Financial Statements.

${ }^{23}$ IFRS Conceptual Framework, 4.25b.

${ }^{24}$ Switzerland: Art. 698(2) ss. 4 CO; Germany: $\S 174(1)$ AktG; UK: French, Mayson and Ryan, Company Law, 12.1; Japan: $\S 238(1)$ JCC; different in the US: $\S 170$ Delaware General Corporation Law; see also Klein and Koffee, Business Organization and Finance, Legal and Economic Principles, pp. 380 et seq.

${ }^{25}$ Cash flow from operations (IAS 7.6, 13), investments (IAS 7.6, 16) and financing (IAS $7.6,17)$.

${ }^{26}$ See IAS 7.14. $\quad{ }^{27}$ See IAS 7.16. 
of the sale of a good (operating cash flow), a disinvestment (investing cash flow) or the result of a salary payment (operating cash flow).

The aggregate amount of the cash flow from operating and investing activities is the free cash flow. It shows the potential of a company to make payments related to its financing to banks and shareholders. ${ }^{28}$ The free cash flow is an important figure in the analysis and valuation of companies. $^{29}$

The cash elements of the profit are the elements which can be determined without the exercise of any discretion. Cash-related figures are objective figures; they are either correct or false, but never fungible under the exercise of discretion.

\subsection{Other elements of the profit}

These cash-related figures show the cash flow, not the profit. Profit or loss is not only inflow but also 'enhancements of assets or decreases of liabilities' and 'depletions of assets or incurrences of liabilities.' Enhancements or depletions of assets and decreases or incurrences of liabilities are not cash-relevant and are thus not shown in the cash flow statements. Enhancements or depletions of assets and decreases or incurrences of liabilities cannot be determined objectively. They require the exercise of discretion by the board and the management.

It is paramount that the board and the management exercise their discretion in the interest of the company only.

\subsection{Examples}

In order to illustrate how enhancements or depletions of assets and decreases or incurrences of liabilities influence the company profit in view of their sensitivity to conflict of interest the following examples are given.

Real estate held as an investment: real estate held as an investment is valued according to the IFRS Rules in the initial valuation at cost value, ${ }^{31}$ in consecutive valuations at cost value or fair value, ${ }^{32}$ depending on the

\footnotetext{
${ }^{28}$ Behringer, Cash-flow und Unternehmensbewertung, pp. 166 et seq.; for the concept of equity as risk reserve see Handschin, 'Das Eigenkapital als Risikoreserve', pp. 80 et seq.

29 For the discounted cash flow evaluation see Rappaport, Creating Shareholder Value, pp. 1 et seq.

30 IFRS Conceptual Framework, 4.25a and 4.25b.

31 'Investment property', IAS 40.20. ${ }^{32}$ IAS 40.30.
} 
valuation scheme which the company has chosen. If the company opts for the fair value option, an increase in valuation leads to a distributable profit. $^{33}$ A decrease of value leads under both options to expenses. ${ }^{34}$ Commercial law accounting rules allow only the cost-value option. ${ }^{35}$

Shares, bonds, financial instruments and securities: shares, bonds, financial instruments and securities are valued according to the IFRS Rules in the initial and consecutive valuations at fair value. ${ }^{36}$ An increase in valuation may lead either to distributable profit or to additional equity, depending on whether the financial asset is held or available for sale. ${ }^{37}$ Commercial law accounting rules allow increasing the value of financial instruments only if they have a market value. ${ }^{38}$

Provisions: if a company is threatened with a lawsuit, the threat itself does not lead to expenses, but to potential expenses. It might be necessary to make a provision. 'A provision is a liability of uncertain timing or amount ..., the settlement of which is expected to result in an outflow from the enterprise of resources. ${ }^{39}$ A provision should be recognised when:

(a) an entity has a present obligation (legal or constructive) as a result of a past event; (b) it is probable that an outflow of resources embodying economic benefits will be required to settle the obligation; ... ${ }^{40}$

... [A]n outflow of resources ... is regarded as probable if the event is more likely than not to occur, i.e. the probability that the event will occur is greater than the probability that it will not. ${ }^{41}$

This so-called 50 per cent rule means that a full provision has to be made if the risk of a liability is larger than 50 per cent. Commercial law accounting rules also allow a proportional provision corresponding to the risk, ${ }^{42}$ e.g. a 40 per cent provision if the risk is 40 per cent.

33 IAS 40.35. ${ }^{34}$ IAS 40.35, IAS 40.56, IAS 16.63, IAS 36.59, et seq.

35 Switzerland: Arts. 665, 667 and 960 CO; Germany: § 253 HGB; Japan: § 285 JCC. Also cf. 'Cost model', IAS 16.30.

${ }^{36}$ All financial instruments are measured initially at fair value. IAS 39, IAS 21, IFRIC 9, IFRIC 10; many financial instruments are carried at fair value (IAS 39.45), some at acquisitions costs (IAS 39, IAS 21, IFRIC 9, IFRIC 10).

37 IAS 39.55: '(a) A gain or loss on a financial asset or financial liability classified as at fair value through profit or loss shall be recognised in profit or loss. (b) A gain or loss on an available-for-sale financial asset shall be recognised directly in equity, through the statement of changes in equity'.

38 Switzerland: Art. 667 CO; Japan: $\S 285(2)$ JCC. This is different in Germany: § 253 HGB, such increase of value leads to a mandatory increase in hidden reserves.

39 IAS 37.10. ${ }^{40}$ IAS 37.14. ${ }^{41}$ IAS 37.23.

42 Switzerland: Art. 669 CO; Germany: § 249 HGB; Japan: $\S 287(2)$ JCC; for the US: 'contingent liabilities', SFAS 5, paras. 1 and 3. 


\subsection{Determination of the company profit, subjective criteria}

The above examples show that the profit of the company is also the result of an analytic procedure, of the application of discretion. This discretion or control over the analytic procedure rests with the board of directors.

Real estate held as an investment: the company has to decide if it applies cost value or fair value in consecutive valuations. If fair value is applied it has to decide on the valuation method, on the rental income, the interest rate, the costs and the risk factor on which the valuation is to be based. Even within the rules regarding fair value valuation deviations from one valuation to another valuation regarding the same property of 20 per cent to 30 per cent are normal. ${ }^{43}$

Shares, bonds, financial instruments and securities: the fair value of traded shares follows the market value or the earnings value, depending on the use of the specific asset. The decision on whether an increased valuation leads to additional equity or additional (distributable) profit depends on whether the company assesses the asset as held or available for sale. ${ }^{44}$

Provisions: the rule that a provision in the full amount of the potential outflow has to be made, if the outflow is more likely to occur than not, means that a 55 per cent chance of an outflow leads to a full provision whereby a 45 per cent chance leads to no provision at all. The respective decision by the company is not easy, especially if the probabilities are more or less equal. The accounting rules regarding provision in commercial law are less vulnerable to this risk. ${ }^{45}$ A 45 per cent risk that an event will occur leads to a corresponding provision (and not no provision) as well as a 55 per cent risk that an event will occur leads to a 55 per cent provision of the potential outflow (and not a 100 per cent provision).

\subsection{Conclusion}

As a conclusion we see that the profit of a company is also the result of the application of accounting and valuation rules. This holds true for prudence-based commercial accounting rules, ${ }^{46}$ and more so in true and fair

43 Volatility in land prices are assumed up to 50 per cent in some regions. Brueggeman and Fisher, Real Estate Finance and Investments, p. 295.

44 'Held for sale', IFRS 5; 'available for sale', IAS 39; Lüdenbach and Hoffmann (eds.), Haufe IFRS-Kommentar, § 28, MN 34 et seq.

45 Switzerland: Art. 667 CO; Japan: $§ 285(2)$ JCC. This is different in Germany: § 253 HGB, such increase of value leads to a mandatory increase in hidden reserves.

46 Switzerland: Arts. 665, 667 and 960 CO; Germany: § 253 HGB; Japan: $§ 285$ JCC. Also cf. 'Cost model', IAS 16.30. 
value-based accounting rules which concede a large amount of discretion to the top management when it comes to the valuation of the assets of the company.

True and fair based rules allow, for example, the revaluation of fixed assets to the real value, even if the real value is higher than the production or purchase value. Furthermore, true and fair asset valuation is often based on capitalised income value or cash flow and not on its substance value or production cost. True and fair rules assess the value of an asset by looking into the future, in particular by estimating the future income the asset can generate. Prudent valuation of assets reduces the company profit; aggressive valuation of assets increases the company profit.

\section{Competence to define the figures}

\subsection{Principles}

The choice of the applied valuation rules rests with the board of directors. The financial control and the preparation of the financial statements is a non-transferable and unalienable duty of the board of directors. ${ }^{47}$ The competence to prepare the financial statements includes the competence to exercise discretion whenever valuation rules require.

The board of directors has to decide on the choice of valuation principles and rules. It is responsible for the preparation of the annual report which includes the financial statements and the motion to the general assembly of shareholders regarding the use of the distributable profit.

\subsection{Examples}

The board has to assess the future potential of each group of assets or liabilities as the basis for its valuation. It has to make these decisions in the best interest of the company. The discretion of the board and its impact on the profit is shown by the following examples.

Real estate held as an investment: the company has to decide whether it applies cost value or fair value in consecutive valuations. The fair value valuation leads in times of a booming real estate market to higher valuation in the consecutive years and thus to a higher distributable profit. If the company applies fair value, it further has to decide on the

47 Switzerland: Art. 716a CO; Germany: the executive board ('Vorstand') is obliged to prepare the financial statement, the non-executive board ('Aufsichtsrat') controls the financial statement $\S 170 \mathrm{AktG}$; Japan: § 281(1) JCC. 
parameter of the real estate valuation, on the expected rental income, the expected interest rate and the risk that the expectations are wrong (risk rate). A prudent board assumes high interest and risk rates and low rent income, a rather confident board the opposite.

Let us assume the construction cost of the real estate was 1,500 , the yearly net rent income is 105 ( 7 per cent) annually, the interest rate (cost of capital) is at 5.3 per cent, the risk rate 4.7 per cent and the building has a lifetime of twenty years. In this case the fair value (income value) of the property is 2,000 . (If we apply a yearly rent income of 79.5 (5.3 per cent) instead, the fair value would be 1,429 or, if we assume a higher interest rate of 9 per cent and risk rate of 2 per cent the fair value would be 2,655.)

Shares, bonds, financial instruments and securities: the company has to decide, if a specific asset is available for sale or held for sale. It has to make an assessment regarding each relevant asset and come to specific conclusions. In our example the financial instrument was purchased for 1,000, but has a present value of 1,500 . If it is available for sale, the difference amount is equity and amounts to an evaluation surplus, if held for sale it is profit. ${ }^{48}$ In this situation, the allocation of the asset, held for sale or available for sale, decides whether the difference amount is profit or not. The practical relevance of this decision of the board becomes evident if the asset loses value in later years. If the difference amount was booked in the valuation surplus, the depletion of the asset leads to the dissolution of the surplus, but not a loss. If the difference amount was profit and was distributed as such to the shareholders, the depletion of the asset leads to a loss and the cash/equity distributed to the shareholders is missing.

Provisions: the company has to assess the risks related to the outflow and decide whether the outflow is more likely to occur than not. Let us assume the company is threatened by a law suit covering a payment of 500. The risks to win or lose are more or less equal. If the board comes to the conclusion that the risks to pay are bigger than the chances not to pay, it has to make a provision of 500. If the risks to pay are estimated to be below 50 per cent, no provisions have to be made.

Balance sheet example: the practical relevance of the above described decisions is shown by the following balance sheet example (Table 16.1). It shows two companies. Company A applies an optimistic valuation approach and assumes a positive scenario, whereby company B applies a prudent or conservative valuation and assumes a prudent scenario.

48 'Held for sale', IFRS 5; 'available for sale', IAS 39; Lüdenbach and Hoffmann (eds.), Haufe IFRS-Kommentar, § 28, MN 34 et seq. 
Table 16.1: Optimistic valuation approach v. prudent valuation approach

\begin{tabular}{lllr}
\hline \hline Corporation A & & Corporation B & \\
\hline Assets & Value & Assets & Value \\
\hline Bank account & 1,500 & Bank account & 1,500 \\
Debtors & 1,000 & Debtors & 1,000 \\
Financial assets & $1,500^{49}$ & Financial assets & 1,500 \\
Real estate & 2,000 & Real estate & 1,500 \\
All assets & 6,000 & All assets & 5,500 \\
\hline Liabilities & & Liabilities & 3,500 \\
\hline Bank debts & 3,500 & Bank debts & 500 \\
All liabilities & & Provisions & 4,000 \\
\hline Equity & 3,500 & All liabilities & \\
\hline Legal capital and reserves & 1,000 & Legal capital and reserves & 1,000 \\
Valuation surplus & & Valuation surplus & $500^{50}$ \\
Profit & $1,500^{51}$ & Profit & 0 \\
All equity & 2,500 & All equity & 1,500 \\
\hline \hline
\end{tabular}

The decisions of the board regarding the valuation of real estate, financial assets and provisions influence directly the distributable profit of the company. This decision is of crucial importance for the company. If the assets are valuated at a value which is too high, the company shows high profits and will be tempted to distribute a part of this profit as dividends to the shareholders. There is a risk that such (unjustified) dividend payments withdraw necessary liquidity from the company and put the company at risk if the economic situation

49 Both the prudent and the optimistic valuation valuate the asset at the present value of 1,500 . Company B (prudent) books the difference amount to the valuation reserves (FN 50), company A (optimistic) to the profit.

50 The valuation surplus is a consequence of the higher valuation of the financial assets. The allocation of the revaluation to the valuation surplus leaves the profit unchanged.

51 The profit of 1,500 derives from the value increase of the financial assets (500) and the real estate (500) and the omission of the provisions (500).

52 Company B (prudent) does not show a profit, since it does not valuate the real estate at a true and fair value and makes a provision for the risk. Further it books the increase in value regarding the financial assets in the valuation surplus. 
Table 16.2: The economic situation aggravates: optimistic v. prudent company

\begin{tabular}{lclr}
\hline \hline Corporation A & & Corporation B & \\
\hline Assets & Value & Assets & Value \\
\hline Bank account & $500^{53}$ & Bank account & 1,500 \\
Debtors & 1,000 & Debtors & 1,000 \\
Financial assets & $1,000^{54}$ & Financial assets & $1,000^{55}$ \\
Real estate & $1,500^{56}$ & Real estate & $1,500^{57}$ \\
All assets & 4,000 & All assets & 5,000 \\
\hline Liabilities & & Liabilities & \\
\hline Bank debts & 3,500 & Bank debts & 3,500 \\
Debt to claimant & $500^{58}$ & Debt to claimant & 500 \\
All liabilities & 4,000 & All liabilities & 4,000 \\
\hline Equity & & Equity & \\
\hline Legal capital and reserves & 1,000 & Legal capital and reserves & 1,000 \\
& & Valuation surplus & 0 \\
Loss & 1,000 & Profit & 0 \\
All equity & 0 & All equity & 1,000 \\
\hline \hline
\end{tabular}

aggravates. ${ }^{60}$ The decisions by the board regarding the valuation of assets should occur unbiased and in the best interest of the company.

These risks are illustrated in the second balance sheet example (Table 16.2). The example assumes that corporation A paid a dividend of 1,000 (reduction of bank account to 500); whereas corporation B paid

53 The bank account is reduced due to the cash dividend payment as a consequence of the high company profit shown in the previous period.

54 The reduction of the value of the financial assets leads to a loss.

55 The reduction of the value of the financial assets leads to the dissolution of the valuation surplus, there is no effect on the profit.

56 The depletion of the real estate makes a revaluation necessary and leads to a loss.

57 The prudent valuation of the real estate of 1,500 in the previous period makes it unnecessary to adjust the value.

58 The debt to claimant is a new liability which is an expense and increases the loss.

59 Company B was prudent and included a provision in the balance sheet of the previous year. The realisation of the risk (lawsuit lost) is not affecting the income.

60 Other than conflict of interest in public law, this conflict of interest may lead to significant economic losses (see Auby, 'Conflict of interest and administrative law', Chapter 8 in this volume, pp. 152-153). 
no dividend. Further, the example assumes, that the financial assets have a value of $1,000,{ }^{61}$ the real estate a value of 1,500 and that the law suit was lost and the provision of 500 turned into a liability.

\subsection{Integrity of the decision-making process - prevention of conflict of interest}

The only way to solve this problem is to ensure that the persons who make these decisions on behalf of the company or who participate in the decision-making process, act only and exclusively in the interest of the company. For this reason, the incentive structures must assure that persons who make these decisions on behalf of the company or who participate in the decision-making process are not in a conflict of interest when making decisions affecting the valuation of assets and risks. ${ }^{62}$ In other words, they must not have a personal interest in the result of these decisions. If their remuneration is linked to the company's profit, they are unable to act independently and are in fact in a conflict of interest.

\subsection{Relevant and irrelevant conflict of interest}

Whether a board member is in a relevant conflict of interest is always a matter of degree. The conflict of interest and the economic impact of the conflict of interest must be of a certain importance in order to be legally relevant, other - unimportant - conflicts of interest are permissible. ${ }^{63}$ The mere fact that a board member has a certain financial interest in a decision which he has to make for the company is not enough.

The criteria are unclear and imprecise. The conflict of interest has to be analysed and it has to be determined whether in the specific situation, there is a risk that the board member does not act in the best interest of the company. The higher the amount at stake, the more probable is a relevant conflict of interest.

Such a conflict of interest exists whenever the remuneration of these persons fully or partially depends on the profit or on balance sheet

61 Given a 30 per cent drop in value.

${ }^{62}$ Ill-perceived incentives influence the decision-making. See Roth, 'Conflict of interest: compliance and its contribution to corporate governance in the financial services sector', Chapter 14 in this volume, p. 261.

63 '[C] onflicts of interest are permitted if the procedures and results seem generally to be fair.' Orts, 'Conflict of Interest on Corporate Boards', p. 144. 
figures which are in fact a result of the board's and the managements' decision process and subject to their discretion.

This means that a remuneration scheme where board members and persons participate in the determination of such figures is not compliant with the principles of good corporate governance.

\section{Bonus rules and organisational concepts which reduce conflict of interest}

\subsection{General remarks}

The result - that bonus rules which relate to the profit of the company are not compliant with the law and the principles of good corporate governance - shows that the definition of the criteria for the determination of board and management pay is more complicated. As we recall, all other forms, including the determination by the assembly of shareholders, have disadvantages, and hence, the link of the management and board pay to the company's success seemed an attractive option.

Therefore, it makes sense to consider remuneration schemes which link the pay to the economic success of the company without the disadvantages and the risks described above. There are basically two possibilities to solve this problem: to introduce an organisational structure to reduce the conflict of interest as a result of performance-based remuneration schemes or to adopt a remuneration scheme which relates more to objective figures or to figures which are determined based on prudence-based valuation rules. ${ }^{64}$ This reduces the risk that the defined profits are fictitious.

\subsection{Audit committees, profit-based remuneration rules only for management?}

Even if the full board assumes responsibility for the annual report, a structure could be put in place which would allow only certain members of the board to participate in the preparation and preparatory discussions regarding the accounting figures.

According to the Swiss Code of Best Practice sections 23 and $24,{ }^{65}$ the audit committee should consist of non-executive, preferably

64 See section 6.3 .

65 Available at www.ecgi.org/codes/documents/swiss_code_feb2008_en.pdf (last accessed 26 June 2012). 
independent members of the board of directors, who should be financially literate and do not participate in any bonus schemes linked to the profit of the company. The audit committee 'should form an independent judgement of ... the annual financial statements'. Similar to the compensation committee, which has the purpose to reduce the conflicts of interest regarding the set up of the payment, the audit committee would ensure that the valuation decisions which influence the company profit are made in the best interest of the company. If it is assured that board members with a profit-based remuneration do not participate in this procedure, conflicts of interest can to some extent be minimised. This model defines a general rule of corporate governance which is valid in corporate law in general. Profit-based remuneration systems are only compliant if the payment of the board members, who are primarily concerned with the decisions regarding the balance sheet figures of the company, is excluded from such systems. For the excluded board members other remuneration systems have to be applied.

In view of the fact that the board of directors bears responsibility for the definition of the figures and the preparation of the annual report, a profit-based remuneration system which applies only to the members of the management, seems acceptable. However, in many companies the board's competence is only formal and it is in fact the management which prepares and understands the figures and the board simply relies on them. In that case, the formal competence of the board does not justify the application of profit-based remuneration systems for the management of the company, certainly not for those persons who prepare the accounts. Profit-based remuneration systems for the management are only compliant if the board is in fact capable of understanding the valuation decisions and proposals by the management, in particular the Chief Financial Officer (CFO). If it is ensured that the respective decisions are effectively (and not only formally) made by the board of directors (and not the executives), a remuneration scheme for the management which is profit-based does not give rise to conflict of interest issues.

\subsection{Prudence-based valuations?}

The above examples have shown that true and fair accounting is more vulnerable to conflicts of interest. The traditional prudence-based valuation allows less discretion when it comes to 'create' profits based on 
changed valuations. Many possibilities to revaluate assets which are compulsory in true and fair bookkeeping are not allowed in prudencebased accounting. ${ }^{66}$

The conflict of interest related to profit-based remuneration rules can therefore be reduced by the application of prudence-based valuation rules. Such valuation rules are in use in most continental European legislations and mandatory for the formal commercial accounts. If we apply prudence-based accounting rules to our examples, the discretion of the board remains smaller. This in turn will reduce the risk of the distributable profit becoming too high.

Prudence-based accounting rules apply for real estate held as an investment at cost value, which means that the company can only valuate the real estate at cost minus the necessary depreciations. The at cost valuation does not eliminate the valuation risk, but it reduces it. The same (cost value) applies for all financial assets other than current assets with a market value. Finally, the rules regarding the formation of provisions require a provision in the amount of the probability of the outflow, which reduces power of discretion and its effects of the exercise of discretion in border cases significantly. A 45 per cent chance of an outflow of 500 required a reserve of 225 , a 55 per cent chance of 275 . The leverage of the decision 45 or 55 per cent is much smaller, than under the IFRS rule. ${ }^{67}$ Prudence-based valuation rules allow less discretion related to the management's valuation-decisions and are thus more 'immune' to conflict of interests. Nevertheless, to propose a return to a pure at cost value bookkeeping would be the wrong reaction to this problem. The wheel of time cannot be put back and the advantages of a true and fair accounting, in particular in terms of transparency, are overwhelming.

\subsection{Cash-flow-based remuneration systems}

When defining the profit, we have seen, that the cash-related elements of the profit can be determined objectively, which makes the cash flow, especially the free cash flow as the amount of cash generated to make

66 Switzerland: Arts, 665, 667 and 960 CO; Germany: § 253 HGB; Japan: § 285 JCC. Increasing the value of financial instruments is allowed only if they have a market value: Switzerland: Art. 667 CO; Japan: $\S 285(2)$ JCC. Not so in Germany: $\S 253$ HGB, such increase of value leads to a mandatory increase in hidden reserves.

67 See IAS 37.23. 
payments related to the financing of the company, a feasible reference figure to determine performance-based remunerations. Of course, the cash flow ignores many parameters which can be relevant to determine the performance of the company such as 'enhancements of assets or decreases of liabilities' and 'depletions of assets or incurrences of liabilities. ${ }^{68}$ For a broad picture the reference figure of the free cash flow is nevertheless helpful. ${ }^{69}$ Other than profit or equity-based figures, the free cash flow can be determined objectively and the risk of a conflict of interest is reduced.

\subsection{Specific parameters and benchmarking}

The company profit is a relatively easy to determine criterion. Apart from its exposure to conflicts of interest, it bears the risk of setting wrong incentives.

For this reason, specific parameters which can be determined objectively, but which relate to company- and function-specific figures, such as market share, product quality, achievement of a specific success, absolute or in relation to competitors, etc. alone or in combination with financial data may be chosen. For instance, criteria could be chosen that compare a group of competing companies in certain key variables. ${ }^{70}$ The remuneration could thus be measured in relation to the competitors, ensuring a more objective method to measure the performance of the management and the board of directors (benchmarking).

It is also possible to link bonus payments to the achievement of a specific business plan. This possibility indicates that 'conflicting conflicts of interest' can reduce the negative effect of success-based remuneration systems. If the management pay is linked to the achievement of a specific business plan, however, another conflict of interest is inherent to this approach as there is an incentive for the management to draw up a business plan in an easily reachable way, thus setting an incentive to take too little risk compared to the company's risk bearing ability. Due to this

${ }^{68}$ IFRS Conceptual Framework, 4.25a and 4.25b.

69 It is used for the discounted cash flow method and thus a relevant figure to determine the value of a company. Behringer, Cash-flow und Unternehmensbewertung, pp. 147 et seq. and p. 166.

70 Davis, Worthington and Micheler, Gower and Davies Principles of Modern Company Law, pp. 14-15. 
diametric effect it might at least ease in combination with a profit-based remuneration system the negative effects of the latter system.

The effects of incentives on management and board behaviour are an academic question, which cannot be resolved solely from a legal perspective, but rather from a psychological perspective. The intrinsic motivation for a job may be displaced by an extrinsic motivation through an economic incentive. ${ }^{71}$ This might, despite the economic incentive, lead to less motivation on the job.

\subsection{Holdbacks of compensation to reduce inappropriate risk taking}

For systemically important financial institutions it has been proposed that a relevant part of the remuneration should be held back for several years, ${ }^{72}$ leading to the possibility that the remuneration is due after it has been realised that the assumed valuations were wrong. Such a system allows us to define a profit-based remuneration retroactively and reduces the conflict of interest in the exercise of discretion when valuating assets and liabilities.

\section{Conclusions}

It has been shown that a remuneration system based on profit, which is determined by the board, and under the exercise of its discretion, does not resolve, but rather aggravates the conflict of interest. The real issue is not the 'unjustified' payment to the board and the management, but the 'collateral' cost as a result of showing exaggerated profits, undermining the company's equity by excessive dividend payments.

The suggestion is to define a remuneration system in a way that avoids conflicts of interest when the board and top-management exercise their discretion in valuating assets and liablilities. This can be achieved by specific corporate structures and by linking the remuneration not to the company's profit, but rather to objective figures, for example to cash flows.

${ }^{71}$ Frey and Osterloh, 'Yes, Managers Should be Paid Like Bureaucrats', pp. 96 et seq.

72 See French et al., The Squam Lake Report, pp. 80 et seq. 